\title{
A NEW SPECIES OF LEVITINIA CHUBAREVA AND PETROVA (DIPTERA, SIMULIIDAE) FROM THE GOLAN HEIGHTS, ISRAEL ${ }^{1}$
}

\author{
F. BEAUCOURNU-SAGUEZ*, Y. BRAVERMAN**
}

SUMMARY. Adults, larvae and pupae of Levitinia freidbergi $\mathrm{n}$. sp. are described from a tiny winter stream at Merom Golan in the Golan Heigths. The relation of the new species to $L$. tacobi and to the primitive genera of Prosimuliini is discussed.

Key-words : Diptera. Simuliidae. Levitinia freidbergi n. sp. Golan Heights.

\section{Une nouvelle espèce de Levitinia Chubareva et Petrova (Diptera, Simuliidae) d'Israël.}

RÉSUMÉ. Le genre Levitinia dont les stades imaginaux sont décrits ici pour la première fois montre, chez les adultes, des caractères évoquant le genre Prosimulium tandis qu'à l'état larvaire il est très proche de Gymnopais et Twinnia. Tous les stades de L. freidbergi n. sp. sont décrits. Une étude comparative est faite avec les genres primitifs de Prosimuliini et la seule autre espèce connue du genre : L. tacobi Chubareva et Petrova, 1981.

Mols-clés : Diptères. Simuliidae. Levitinia freidbergi n. sp. Golan Heights.

\section{Introduction}

A new simulid species belonging to the genus Levilinia Chubareva and Petrova, 1981, has been collected in a survey at the Golan Heights, Israel. The samples, taken in March, 1981 and March, 1982, included a relatively abundant material of larvae, pupae and adults both sexes.

This species shows morphological characteristics related to the genus Levitinia a monotypic genus, known only from the larva of $L$. tacobi.

With the exception of Prosimulium (P.) petrosum Rubtsov, recorded in Cedex.

* Laboratory of Applied Parasitology and Zoology, Faculty of Medicine, F 35043 Rennes

** Kimron Veterinary Institute, P. O. B. 12, Bet-Dagan, 50250, Israel.

Accepté le 10 juillet 1986.

1. This work was carried out within the framework of French-Israeli collaboration treaty on the fauna of Simuliidae in Israel, signed in 1981 between the Department of Zoology of TelAviv University (Prof. J. IKugler) and the Laboratory of Applied Parasitology and Zoology of Medicine and Pharmacy of University of Rennes (Prof. J. M. Doby). 
Lebanon (Crosskey, 1967), the Prosimuliini (and particularly the primitive genera) were unknown in this region. However, the Golan Heights present biotops with high altitude and low temperature which provide the adequate climatic requirements for these groups.

\section{Levitinia freidbergi n. sp.}

MALE

Length $3 \mathrm{~mm}$; generally blackish body, especially on scutum, with tendency to greyishness elsewhere; erected setae of clypeus, occiput, scutum and scutellum black at base and yellowish at distal extremity; legs uniformly grey-brown with golden colored setae. Head: eyes holoptic, well developed with two kinds of facets, without stemmatic bulla on the posterior margin of the eye (fig. 1). Antenna blackish with 11 segments; scape with verticille of setae touching the distal rim of the next segment; setae more or less verticiliated on the pedicelle, terminating at the basal third of the 3rd segment, at other sites setae about the length of flagellar segments. Mouthparts very short; maxillary palp short, the last segment slightly longer than the 3rd; sensory vesicle reduced. Clypeus with long erect setae. Thorax strongly arched dorsally; pronotum bare at median part; scutum covered with rather dense fine recumbent setae and sparse semi-erect or erect setae; postnotum regularly convex, bare and without a median longitudinal ridge; katepisternum in profile about as high as long delimited by a shallow and hardly visible mesepisternal sulcus; pleural membrane bare; group of mesepimeral setae extending towards the ventral side under the metathoracic spiracle. Wings hyaline with strong anterior veins; costal vein covered with hair-like macrotrichia, without spiniform macrotrichia; Rs vein clearly forked; basal section of $R$ haired; petiole of vein $\mathrm{M}$ like in Prosimulium; vein $\mathrm{Cu}_{2}$ curved; basal cell easily visible. Legs with uniform color; fore basitarsus narrow, about $2 / 3$ of the length of the tibia; hind leg without pedisulcus and calcipala; length of hind basitarsus $3 / 5$ of tibia (fig. 2, 3, 4). Terminalia: gonocoxite, in ventral view, higher than wide and narrower at its base; gonostylus shorter than gonocoxite, its outer side convex, its inner side almost straight with two apical spinules (visible in magnification $\times 40$ ) (fig. 5); ventral plate small and rectangular with parallel lateral margins and slightly developed forearms ( fig. 7) ; in profile ventral plate is equally wide throught its length and is covered with short and stout hairs (fig. 11, 12); ventral plate at anterior part protruding medially between arms as a dome which does not extend beyond the arms and is fused with the median sclerite; this last sclerite is long, flattened and arched, the distal part moderatly cleft with two ends turned outwards (fig. $8,9,10)$; paramere stick-like not attached to forearm of ventral plate, strongly fused with parameral apodeme of gonocoxite and free at its distal part (fig. 6); sclerotized cerci each bearing about 20 setae. Tergite 9 strongly sclerotized, trapezoid, with posterior part slightly rounded. 

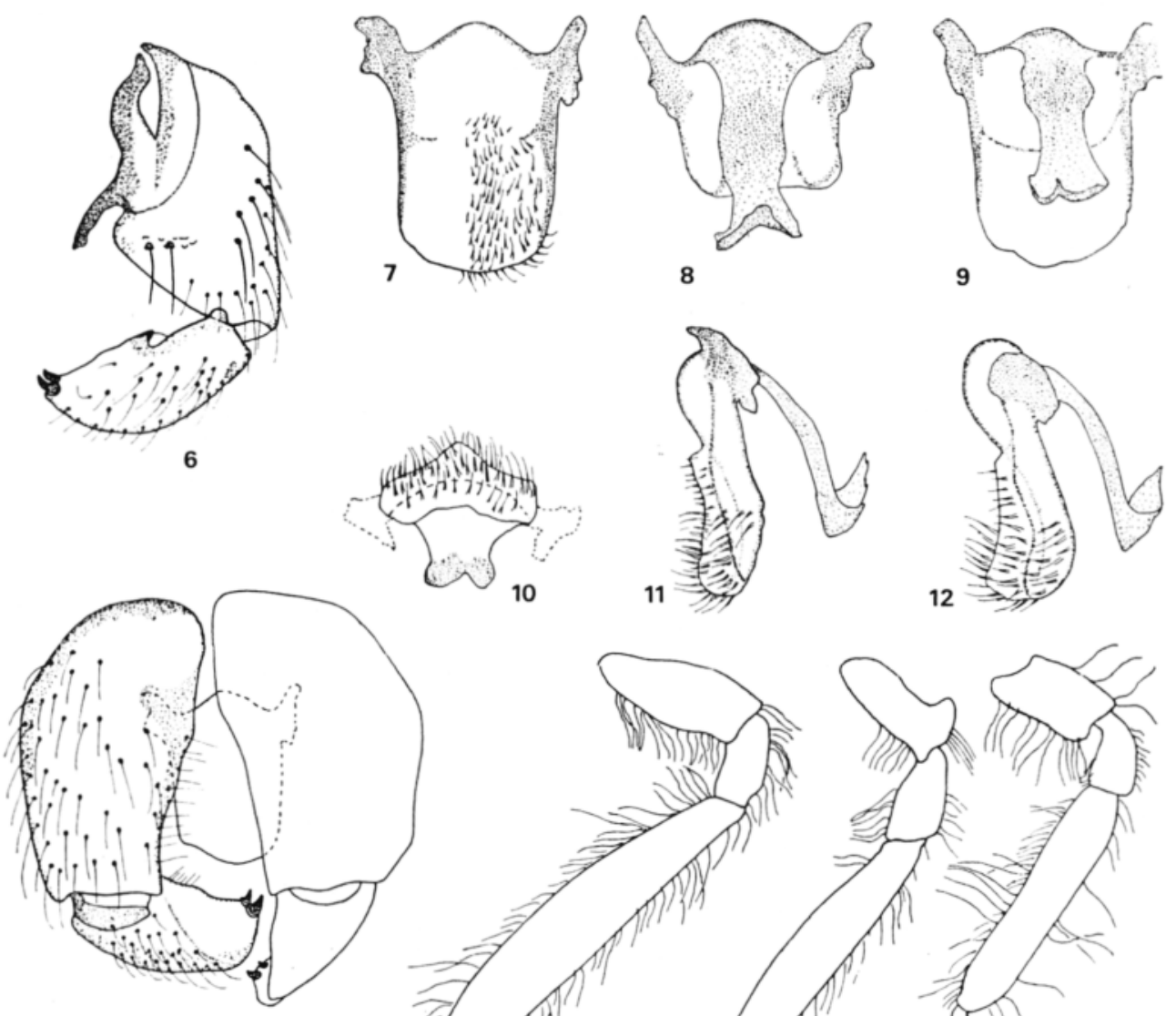

10

11

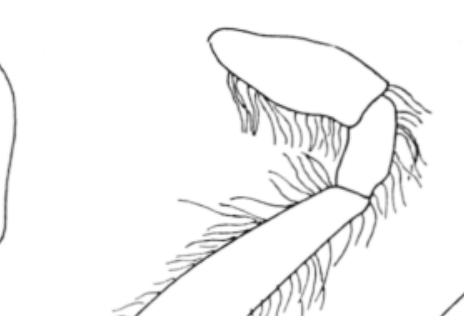

5
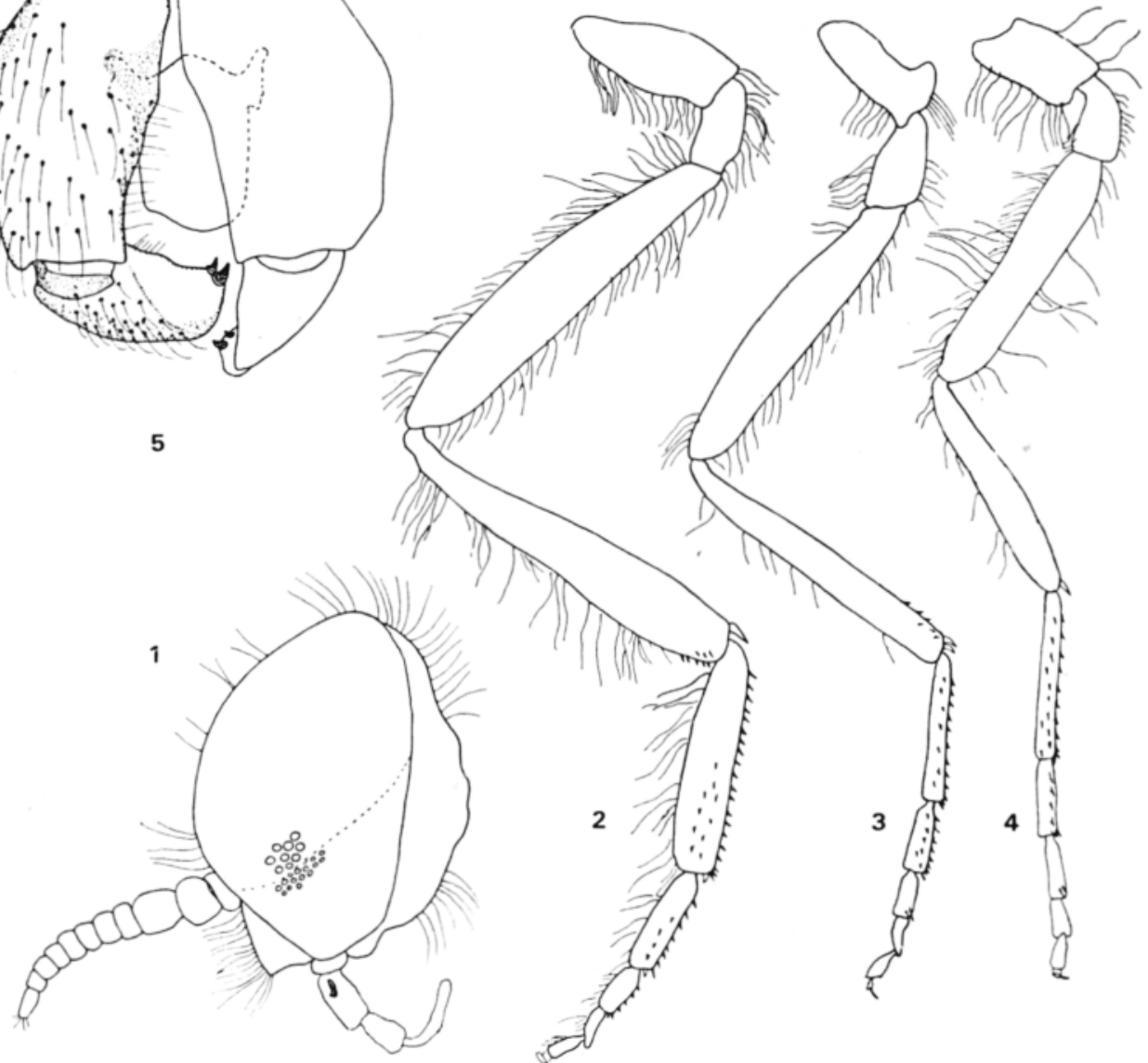

(4)

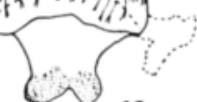


Female

Length 3.5 to $4 \mathrm{~mm}$; wing length $3.5 \mathrm{~mm}$; colour of body greyish-black with yellow-golden setae; scutum almost black as in male; legs grey covered with yellowgolden setae; scutum of pinned specimens with recumbent setae. Head (fig. 13, 14): eyes dichoptic with all facets similar in size; front widens towards vertex and covered with rather long setae which are arranged regularly. Antenna with 11 segments, 1st flagellomere about equal in length and width to pedicel; flagellomeres 2-8 each are half the lenght of the 1st; clypeus blackish with long erect setae distributed allover. Mouthparts normally developed: mandibles with $24+8$ teeth; laciniae with $14+9$ teeth ( $f$ ig. 17,18 ); maxillary palp small, last two segments almost in the same length as the third, sensory vesicle occupies more than $1 / 3$ of $3 \mathrm{rd}$ segment (fig. 16). Thorax: generic characters were given in the male description (fig. 15, 24, 25). Legs : fore basitarsus narrow, half length of tibia; hind basitarsus slightly longer than half tibia (fig. 20, 21, 22); claws relatively long with visible basal tooth that measures $1 / 4$ length of principal tooth (fig. 23). Genitalia (fig. 26, 27): abdomen terminates with small dart-like tip produced dorsally by tergite 9 ; 9 th tergite is wide at base and produces latero-ventral extensions connected with ends of lateral arms of genital fork; from the anterior quarter it is narrower and tapering posteriorly; on its inner ventral face it looks as there is a groove, which indicates a possibility of egg laying in or on appropriate substrate; dorsal cuticle of 9 th tergite covered dorsally with many short setae. Sternite 8 relatively narrow; gonapophyses short with sclerotization lines and 5-6 short setae, not reaching anal lobes (paraproctes); inner anterior angle of each gonapophyses prominent; central part of genital fork narrow, widened anteriorly; arms of genital fork very broad measuring more than half length of median part; anal lobe and cercus separated by membrane moderately sclerotized; cerci almost rectangular, with posterior angle more slender reaching the distal 1/6 of tergite 9 . Spermatheca mushroom-like, with a large unsclerotized area at junction with spermatecal duct.

Pupa

Body length 5-5.5 mm, respiratory filament $4-4.5 \mathrm{~mm}$ (fig. 3). Cocoon absent, except for a few uncolored strands at tip of abdomen, incorporating small pieces of debris. Eight respiratory filaments with two principal trunks, the upper one smaller in its diameter than the lower; variations exist in situation, length and openingangle of filaments (30 up to a maximum of $90^{\circ}$ ); upper trunk always with two filaments, lower with six filaments varying in their situation from specimen to specimen, or even from one side to the other of the same specimen (generally three or four bifurcations) (fig. $28,29,30$ ); integument of frons and thorax with many small irregular granules ( $f$ ig. 35,36 ); trichomes simple and short. Abdomen with fine granular integument; tergal and sternal plates clearly separated by longitudinally striate semi-membranous area; a pair of pleural plates isolated from tergal 


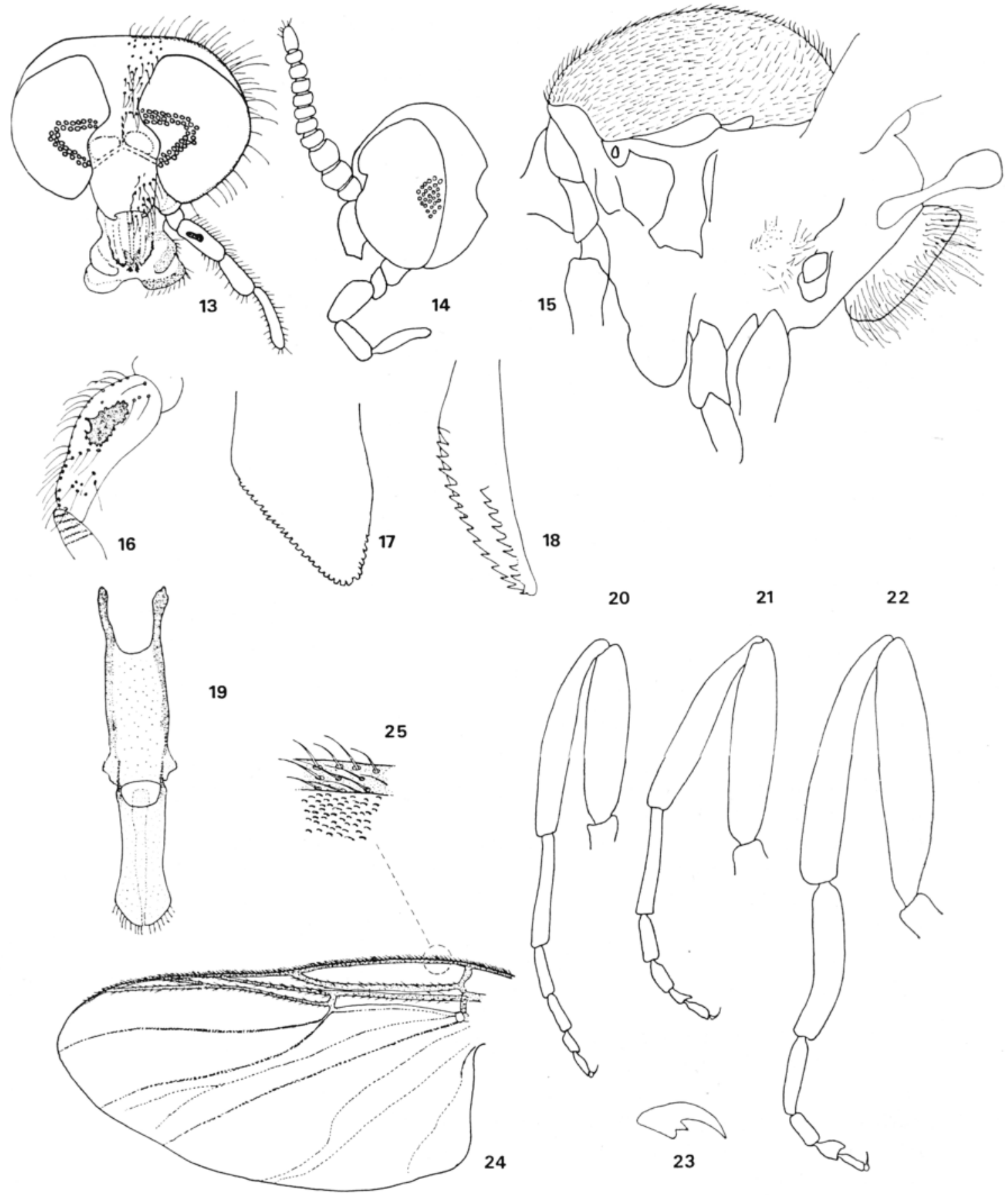

FIG. 13-25. - Levitinia freidbergi n. sp., female. 13,14. anterior and lateral view of head; 15. laterail view of thorax; 16 . 3rd segment of maxillary palp with sensorial pit; 17, 18. mandible and lacinia; 19. cibarium and hypopharynx; 20-22. fore, mid and hind legs; 23. tarsal claw; 25 . wing and details of costal vein. 

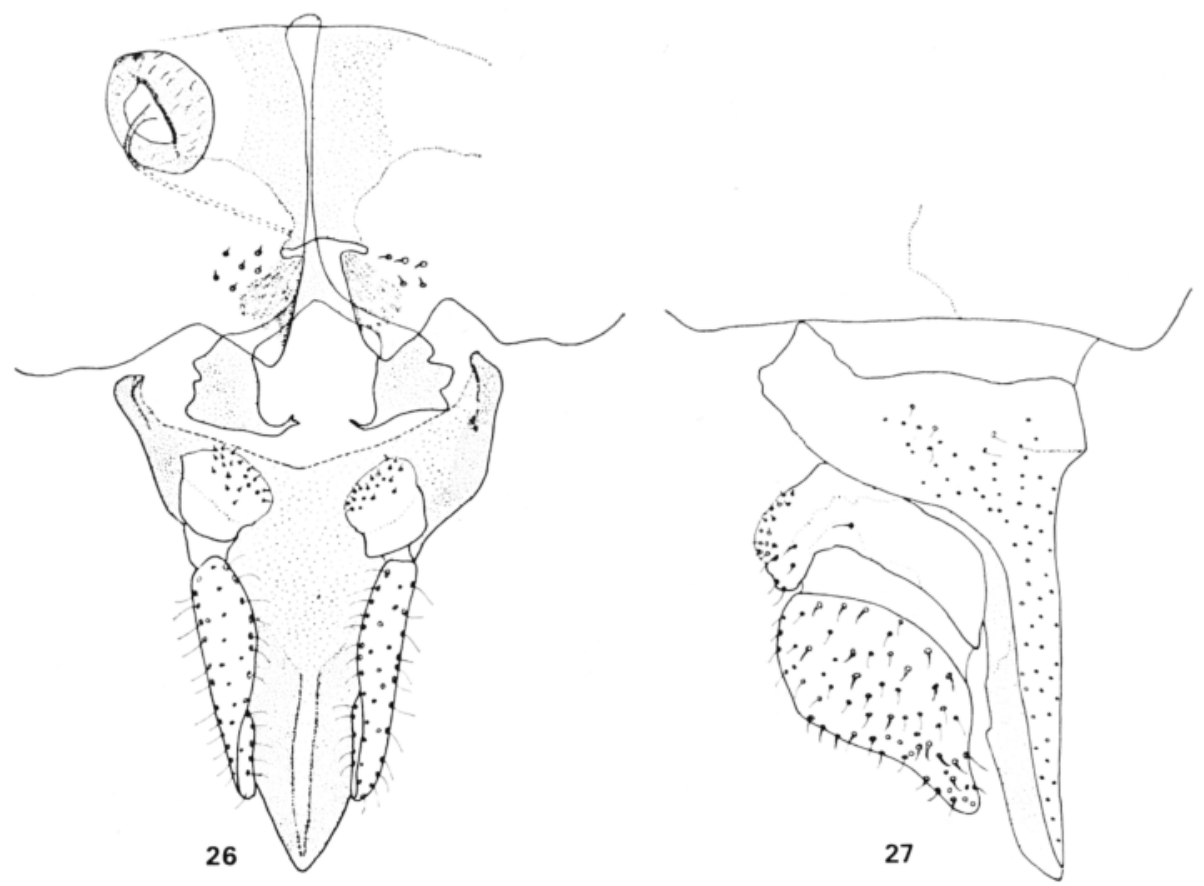

FIG. 26, 27. - Levitinia freidbergi n. sp., female. Ventral and lateral views of genitalia.

and sternal plates in segment 5; sternites 6 and 7 divided in the mid-line by semimembranous striate area. Onchotaxy (fig. 32, 33, 34): sternites 4-7 with two pairs of hooks, well developed in segments 5, 6 and 7; tergites 2-4 with eight hooks more or less developed; tergites 6-8 with discrete line of small spines; segment 9 with two large terminal spines directed dorsally; lateral sides of segment 9 with fine simple or multibranched setae.

\section{LAST INSTAR LARVA}

Length 8-9 mm; color generally grey-yellow, head capsule brown. Lateral margins of head capsule strongly convex like that of the primitive genera Twinnia and Gymnopais. Labral fans absent. Cephalic apotome very narrow at posterior part, widest in median part and tapering then after; head spots consisting of a large and rectangular posteromedian group which extends largely over each side of median line; two anterolaterally subgroups of several small spots (fig. 39). Postgenal cleft without definite shape and very reduced; hypostomal bridge large (fig. 38). Anterior margin of hypostomium with central group consisting of one large, prominent tooth and four reduced lateral teeth; on either side, another 


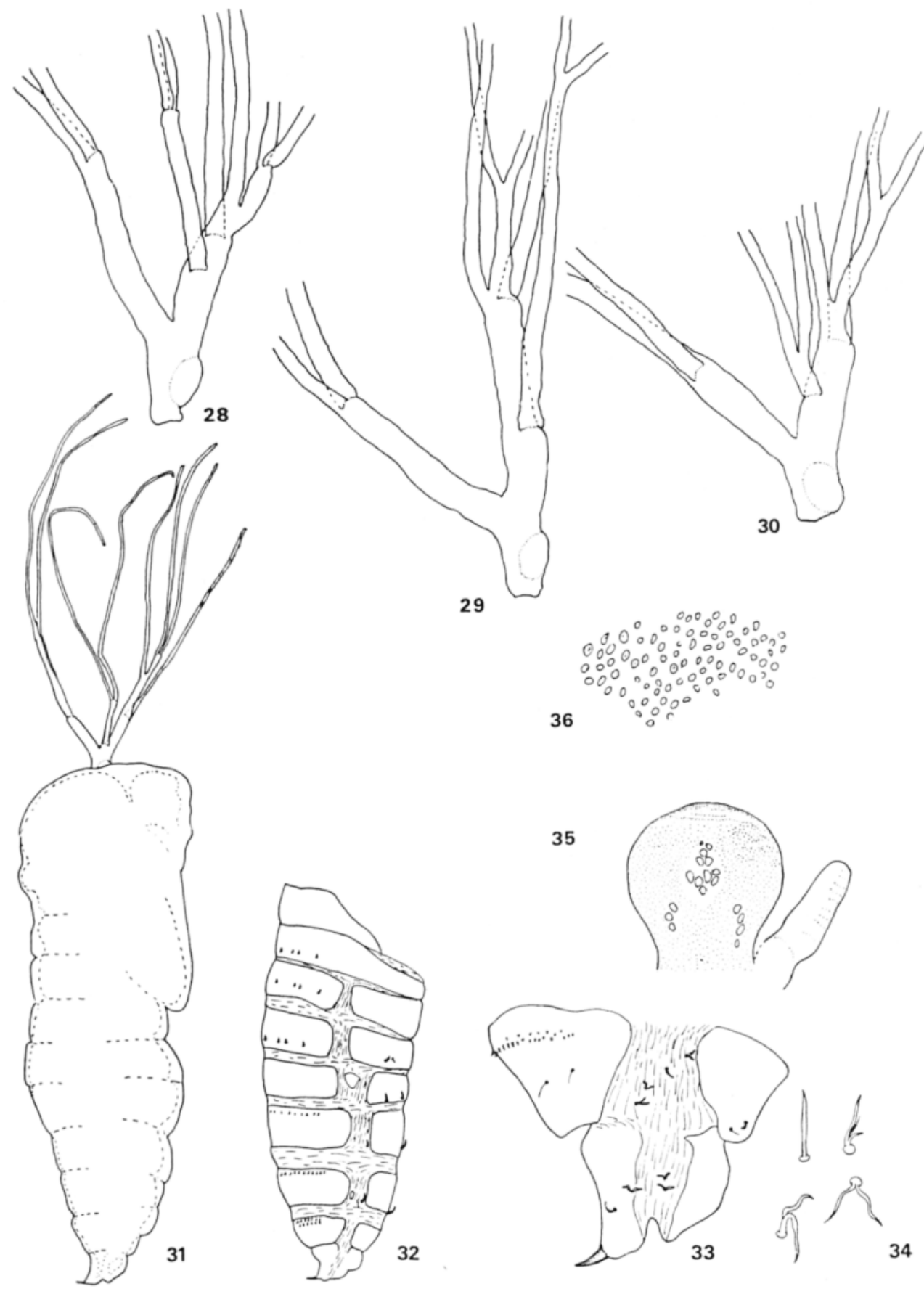

FIG. 28-36. - Levitinia freidbergi n. sp., pupa. 28-30. respiratory fllaments from three different specimens; 31 . general morphology; $32-34$. chetotaxy of abdomen; 35,36 . cephalic plate and details of cuticular ornamentation. 


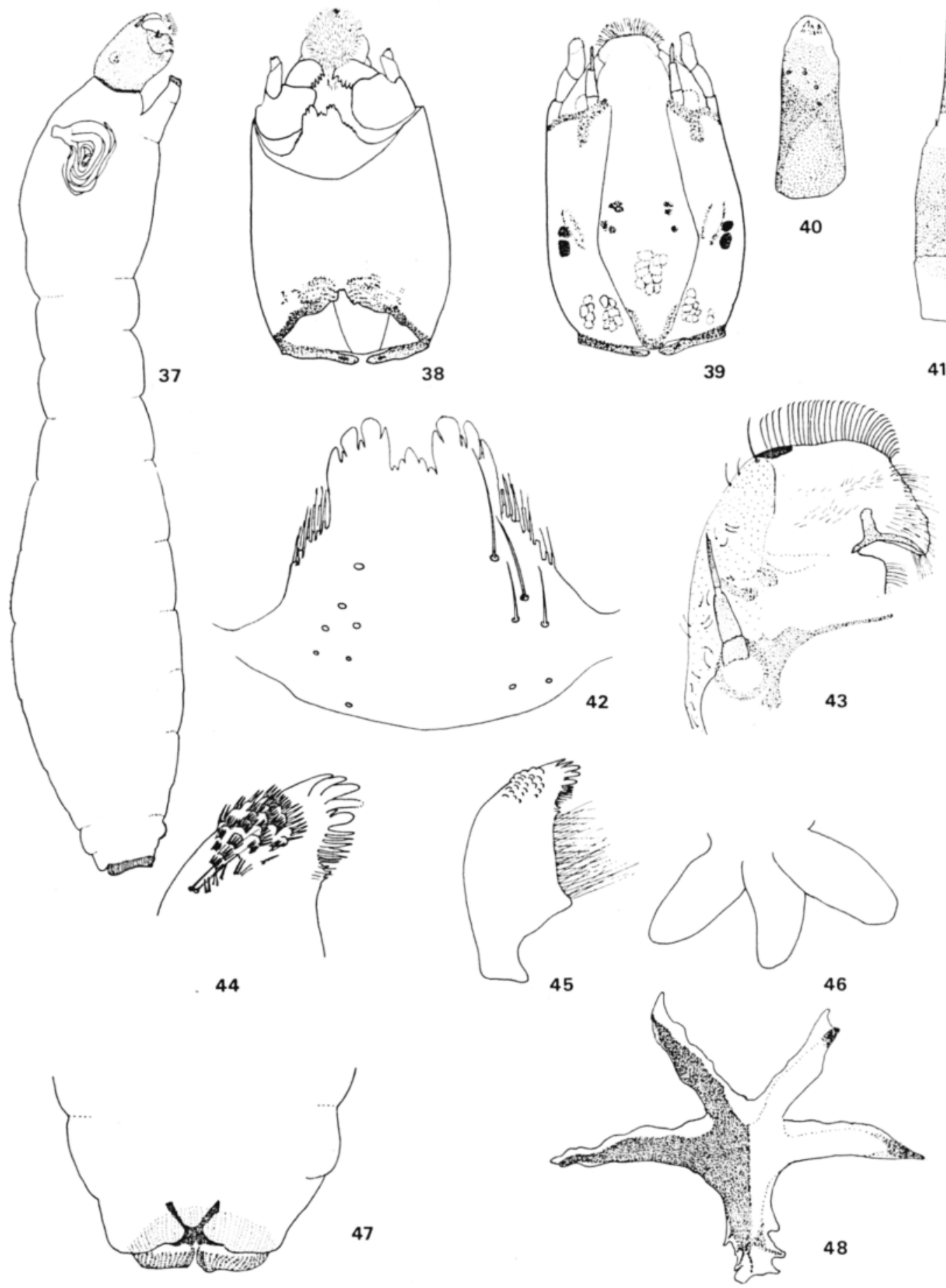

Fig. 37-48. -- Levilinia freidbergi n. sp., larva. 37. general morphology; 38, 39. ventral and dorsal view of head capsule; 40. maxillary palp; 41. antenna; 42. hypostoma; 43. lateral view of labral region; 44, 45. mandible; 46. anal gills; 47. dorsal view of posterior tip of abdomen; 48. anal sclerite. 
group strongly protruding with three spade-like serrated teeth, decreasing in height laterally; lateral margins of hypostomium producing 6-8 very fine and long bristlelike cuticular outgrowths; a sublateral row of 6-7 short setae ventrally on each side of hypostomium (fig. 42). Labrum conical, elongated measuring slightly less than $1 / 3$ of total head capsule length with an anterior median brush (antero-median palatal brush in Craig, 1974); labral brush large, with numerous setae, curving and tapering towards ventral side, more similar to brush of Gymnopais than to paintbrush of Twinnia (fig. 49, 50); before setae 2 C (according to Craig, 1974) a small strongly sclerotized tongue-like area situated on the postero-median part of the brush; on the sides of labrum, sclerites of torma present; epipharynx covered with long setae arranged regularly; intertorma well developed (fig. 43). Short and swollen antenna not reaching labral brush, with pattern like Twinnia, Gymnopais and Prosimulium, but wholly pigmented; 1st segment slightly longer than half length of 2nd; 3rd segment slightly shorter than the 2nd (fig. 41). Mandibles very close to those of Gymnopais particularly by presence of 7-8 irregular rows of distinct spine-like outgrowths of cuticle at the antero-ventral region (fig. 44, 45, 49); each cuticular extension carries 2-6 straight and fine teeth; apex of mandible with five flattened, distally rounded teeth, the 5 th tooth shorter than the 4 th; then 8-11 moderately long subapical teeth, decreasing in diameter; mandibular serrations with 2-3 irregular teeth. Maxillary palp swollen, pigmented part twice as long as widest part (fig. 40); hair tuft at the base fewer than in Prosimulium. Integument of head capsule with numerous secondary short setae.

Body slender, slightly arched, little enlarged in posterior abdominal segments ( fig. 37); a pair of like-bulge tubercles scarcely visible latero-ventrally on segment 8; characteristic anal sclerite with five branches homologous to $\mathrm{X}$-shaped sclerite of Prosimulium and Y-shaped sclerite of Gymnopais and Twinnia (fig. 48); fifth unpaired branch situated perpendiculary to sclerite and not visible in dorsal view; anal gills composed of three simple digitiform lobes (fig. 46); posterior ring of hooks with about 80 rows each of 13-15 hooks; thoracic and abdominal cuticle bare.

Material examined: Israel, Golan Heights, Merom Golan.

Holotype female obtained from a pupa collected 18.3.1982, Y. Braverman; allotype male, 17.3.1981, A. Freidberg; 4 males, 6 females, 12 pupae and ca 100 larvae paratypes, same data as holotype and allotype, Y. Braverman and A. Freidberg. Holotype, allotype and most of paratypes deposited in the Department of Zoology at Tel-Aviv University. Some paratypes deposited in the Laboratory of Applied Parasitology and Zoology, U. E. R. of Medicine and Pharmacy, Rennes, France and ulteriorly in Laboratoire d'Entomologie, Muséum National d'Histoire Naturelle, Paris.

The new species is named after A. Freidberg who collected the first specimens. 


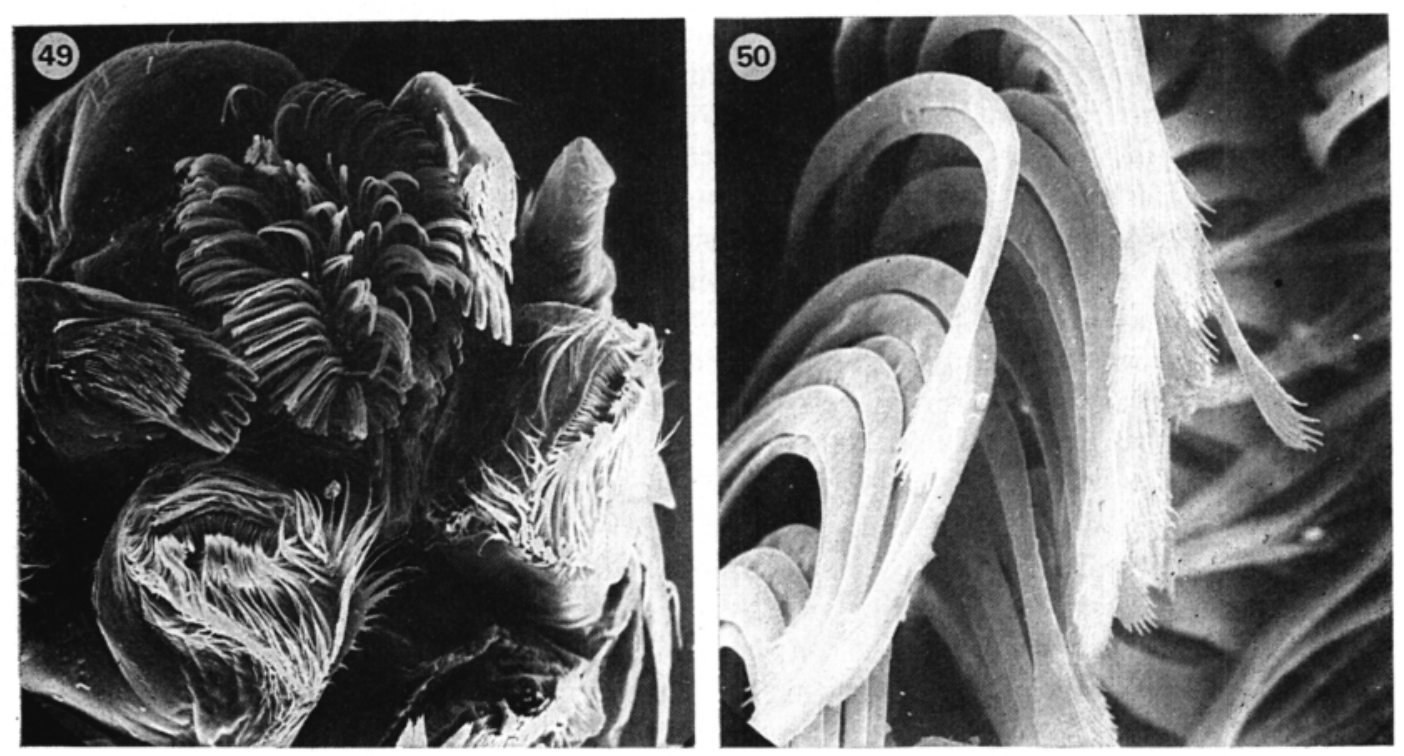

Fıg. 49, 50. - Levitinia freidbergi n. sp., S. E. M. micrograph of frontal region of head capsule; 49. labral brush, comb-like scales of mandible; 50 . apex of median setae of labral brush.

\section{Discussion}

The hitherto monotypic genus Levitinia was proposed for L. tacobi Chubareva and Petrova, 1981, a species that was based only on the description of larvae collected in Tadjikistan. We are placed L. freidbergi n. sp. in Levitinia because of the great similarly between the larvae of both species.

Chubareva and Petrova (1981), Rubtsov and Yankovsky (1984) ranked levitinia in Gymnopaidinae with primitive genera Gymnopais Stone and Twinnia Stone and Jamnback. These two holarctic genera have affinities with Levitinia on account of the larval morphology and the lack of labral cephalic fans. We prefer to follow the classification of Crosskey $(1981,1985)$ and to place Levitinia in the Prosimuliini (Subfamily Simuliinae) to recognize the relationship between adults of Levilinia and Prosimulium Roubaud.

Several characters justify the placement of Levitinia in Prosimuliini : shallow and virtually absent katepisternal sulcus; height of katepisternum equal to length; wing veins without spiniform macrotrichia; vein Rs forked; basal cell present; pleural membrane bare; pedisulcus absent; first tarsomere of foreleg slender; last segment of maxillary palp very short (Crosskey, 1969).

The following is a discussion comparing Levitinia with closely related Prosimuliini. Tables I, II and III summarize the principal generic characters of Levitinia and the possible variations within the 3 genera Gymnopais, Twinnia and Prosimulium in the adult, pupa and last instar larva. This comparison is based on the works of Novak (1957) on Twinnia, Davies (1965) on Gymnopais, Craig (1974) and 
Wood (1978) on both genera, Rubtsov (1959-1964; 1974), Stone (1963; 1964), Crosskey (1969), Rivosecchi (1978) and Peterson (1970; 1981) on Prosimulium. As for Twinnia, the comparison was done with material at our possession (Beaucournu-Saguez and Rivosecchi, 1982).

\section{Anulit (lable I)}

The table $I$ shows noticeable differences between Levitinia and Gymnopais. This last genus is very typical owing to some general characters of the body, eyes, antennae, wings, hairy (coarse, rare and erect) zone of the thorax and in several genitalia structures of the male and female. Despite the fact that Gymnopais has characters of Prosimuliini, Gymnopais looks (with its flat thorax) deviating taxonomically from Simuliidae. According to Davies (1965) it shows affinity to Chironomidae.

In contrast, Levilinia with its normally high and arched scutum could be considered as typical simuliid genus similar to Twinnia and Prosimulium.

TABLE I. - Comparison between the adult stage of four closely related genera belonging to the Prosimuliini.

\begin{tabular}{llcc}
\hline \multicolumn{1}{c}{ Levilinia freidbergi } & \multicolumn{1}{c}{ Gymnopais } & Twinnia & Prosimulium \\
\hline $\begin{array}{l}\text { Eyes normally develo- } \\
\text { ped }\end{array}$ & $\begin{array}{l}\text { Eyes might be small } \\
\text { and dichoptic in the } \\
\text { male }\end{array}$ & $\begin{array}{c}(1) \\
\mathrm{L}\end{array}$ & $\mathrm{L}$ \\
$\begin{array}{l}\text { Without stemmatic bul- } \\
\text { la }\end{array}$ & $\begin{array}{l}\text { Stemmatic bulla pre- } \\
\text { sent }\end{array}$ & $\mathrm{G}$ & $\mathrm{L}$ \\
\hline $\begin{array}{l}\text { Antenna with } 11 \text { seg- } \\
\text { ments }\end{array}$ & 9 segments & $\mathrm{G}$ & $\begin{array}{c}\text { L } \\
\text { (Exceptions } \\
\text { exist) }\end{array}$ \\
\hline $\begin{array}{l}\text { Female mandibles and } \\
\text { laciniae with teeth }\end{array}$ & Without teeth & $\mathrm{L}$ \\
$\begin{array}{l}\text { Thorax strongly arched } \\
\begin{array}{l}\text { Scutum with rather } \\
\text { dense fine recumbent } \\
\text { setae and sparse erect } \\
\text { setae }\end{array}\end{array}$ & $\begin{array}{l}\text { Scutum with coarse, } \\
\text { sparce and erect setae }\end{array}$ & $\mathrm{L}$ & $\mathrm{L}$ \\
\hline $\begin{array}{l}\text { Postnotum rather large, } \\
\text { without median longi- } \\
\text { tudinal ridge }\end{array}$ & $\begin{array}{l}\text { Postnotum rather small } \\
\text { sometimes with median } \\
\text { longitudinal ridge }\end{array}$ & $\mathrm{L}$ & $\mathrm{L}$ \\
\hline
\end{tabular}

(1) The letters $L, G$ and $T$ indicate similarity in the related criterion with the corresponding genera: Levitinia, Gymnopais and Twinnia. 
TABle I (Continued).

\begin{tabular}{|c|c|c|c|}
\hline Levitinia freidbergi & Gymnopais & Twinnia & Prosimulium \\
\hline Pleural membrane bare & $\begin{array}{l}\text { Usually with a small } \\
\text { group of setae }\end{array}$ & $\mathrm{L}$ & $\begin{array}{l}\mathrm{L} \\
\text { (Exceptions } \\
\text { exist) }\end{array}$ \\
\hline $\begin{array}{l}\text { Mesepimeral setae ex- } \\
\text { tending below the meta- } \\
\text { thoracic spiracle }\end{array}$ & $\begin{array}{l}\text { Mesepimeral setae con- } \\
\text { fined above the meta- } \\
\text { thoracic spiracle }\end{array}$ & $L$ & $\mathbf{L}$ \\
\hline Large transparent wings & Narrow fumose wings & $\mathrm{L}$ & $\mathrm{L}$ \\
\hline $\begin{array}{l}\text { Tarsal claw of female } \\
\text { with distinct basal tooth }\end{array}$ & Claw simple & $\mathrm{G}$ & Claw variable \\
\hline $\begin{array}{l}\text { Female with short go- } \\
\text { napophyses }\end{array}$ & $\mathbf{L}$ & $\mathbf{L}$ & $\begin{array}{l}\text { Gonapophyses } \\
\text { variable }\end{array}$ \\
\hline $\begin{array}{l}\text { Anal lobe and cercus } \\
\text { of female separated by } \\
\text { membrane }\end{array}$ & $\begin{array}{l}\text { Anal lobe and cercus } \\
\text { fused into a single scle- } \\
\text { rite }\end{array}$ & $\mathbf{L}$ & $\mathrm{L}$ \\
\hline $\begin{array}{l}\text { Sclerotized spermatheca } \\
\text { with a large transparent } \\
\text { area in its base }\end{array}$ & $\begin{array}{l}\text { Completely sclerotized } \\
\text { spermatheca with scle- } \\
\text { rotization extending a } \\
\text { short distance down the } \\
\text { duct }\end{array}$ & $\begin{array}{c}\mathrm{L} \\
\text { (Spermatheca } \\
\text { sometimes } \\
\text { not sclerotized) }\end{array}$ & $\begin{array}{l}\mathrm{L} \\
\text { (Exceptions } \\
\text { exist) }\end{array}$ \\
\hline $\begin{array}{l}\text { Tergite } 9 \text { of female long } \\
\text { and dart-like }\end{array}$ & Tergite short and blunt & G & G \\
\hline $\begin{array}{l}\text { Gonostylus of male with } \\
2 \text { clearly visible spines } \\
(\times 40)\end{array}$ & $\begin{array}{l}\text { More than } 2 \text { spines, } \\
\text { hardly visible }\end{array}$ & $\begin{array}{l}1 \text { visible spine } \\
\text { (rarely 2) }\end{array}$ & $\begin{array}{l}1 \text { or more visi- } \\
\text { ble spines }\end{array}$ \\
\hline $\begin{array}{l}\text { Ventral plate of male } \\
\text { higher than its width } \\
\text { with anterior arms not } \\
\text { prominent; lateral mar- } \\
\text { gins parallel }\end{array}$ & $\begin{array}{l}\text { Ventral plate wider } \\
\text { than its height with } \\
\text { anterior arms promi- } \\
\text { nent }\end{array}$ & $\begin{array}{l}\text { Width / height } \\
\text { variable; ante- } \\
\text { rior arms pro- } \\
\text { minent; lateral } \\
\text { margins emar- } \\
\text { ginate }\end{array}$ & $\begin{array}{l}\text { Ventral plate } \\
\text { generally wi- } \\
\text { der than its } \\
\text { height with an- } \\
\text { terior arms va- } \\
\text { riable }\end{array}$ \\
\hline $\begin{array}{l}\text { Ventral plate with } \\
\text { dome-like extension to } \\
\text { which the anterior mar- } \\
\text { gin of median sclerite is } \\
\text { fused }\end{array}$ & $\begin{array}{l}\text { Ventral plate without } \\
\text { dome-like extension }\end{array}$ & $\mathrm{L} ?$ & $\begin{array}{l}\mathrm{G} \\
\text { (Exceptions } \\
\text { exist) }\end{array}$ \\
\hline $\begin{array}{l}\text { Paramere reduced to a } \\
\text { stick strongly fused to } \\
\text { parameral apodeme of } \\
\text { gonocoxite }\end{array}$ & $\begin{array}{l}\text { Paramere more deve- } \\
\text { loped, connected to go- } \\
\text { nocoxite by a slender } \\
\text { stem }\end{array}$ & $\mathrm{G}$ & $\begin{array}{l}\text { Paramere dis- } \\
\text { cretily connec- } \\
\text { ted to gonoco- } \\
\text { xite (exception } \\
\text { exist) }\end{array}$ \\
\hline
\end{tabular}


Twinnia and Prosimulium are very close: several authors (one of them Shewell, 1958) propose to consider Twinnia as subgenus of Prosimulium. However, the separation of Levitinia from Twinnia is possible, based on three characters: number of segments of the antenna (11 instead of 9 in Twinnia), absence of stemmatic bulla on posterior margin of eye and claw of female with basal tooth (undeveloped in Twinnia). Several details of the genitalia support this distinction.

While the adults of Levitinia show morphological differences with Twinnia and Gymnopais, no generic character permits to distinct it from Prosimulium. Males of Levitinia isolated from larval stages cannot easily identified. But we must remark male genitalia, while close to Prosimulium, present some own details of structure: ventral plate with anterior part protruding as a dome, median sclerite anteriorly fused to ventral plate, paramere stick-like strongly fused to gonocoxite. Because of these connections, terminalia seem very single and are unusual in genus Prosimulium.

The determination of females of Levilinia is not possible if we only consider the two features: small gonapophyses and tarsal claw with a distinct basal tooth. These characters are found equally in some subgenera within Prosimulium. The specifics of female of $L$. /reidbergi are reflected by the developed dark-like last abdominal tergite. The morphology of this tergite could be an available criterion to separate the two genera. But as the female of $L$. lacobi is not known, it is difficult to decide if the specific shape of 9 th tergite is own to the genus or only to the new species.

\section{Pupa (lable II)}

As for the adult, the pupal stage of Levilinia does not show any character that enables to differentiate it from Prosimulium. However, it can be distincted from Twinnia and Gymnopais by onchotaxy of abdomen, presence of semi-membranous area between tergite and sternite of segment 3 , and number of respiratory filaments.

\section{LARva (table III)}

Contrary to the pupal and adult stages, the larva of Levitinia is morphologically close to those of primitive species of Prosimuliini.

In that tribe there are essentially four genera which belong to the same monophyletic group: Gymnopais, Twinnia, Crozetia and Prosimulium (Crosskey, 1969; Craig, 1974).

The absence of cephalic fans which is considered to be plesiomorphic or apomorphic character (Grenier and Rageau, 1960; Dumbleton, 1962; Davies, 1965; Craig, 1974; Wood, 1978) is the first criterion which enables to associate Gymnopais to Twinnia. The larvae of the two genera are characterized by specific morphology of the head capsule which is narrow at anterior end bearing a labral brush. In the other genera of Simuliidae, the development of the complex structure of labral fans which originated from the labrum caused the widening of head and the loss of functional brush. 
TABLE II. - Comparison between the pupal stage of the four closely related genera belonging to the Prosimuliini.

\begin{tabular}{lcll}
\hline Levitinia freidbergi & Gymnopais & \multicolumn{1}{c}{ Twinnia } & \multicolumn{1}{c}{ Prosimulium } \\
\hline $\begin{array}{l}8 \text { respiratory fila- } \\
\text { ments (L.freidber- } \\
\text { gi) or } 10 \text { (L.tacobi) }\end{array}$ & $\begin{array}{l}\text { 2-4 respiratory fi- } \\
\text { laments }\end{array}$ & $\begin{array}{l}\text { 140r16 respiratory } \\
\text { filaments }\end{array}$ & $\begin{array}{l}\text { Variable number } \\
\text { of respiratory fila- } \\
\text { ments (from 6 to } \\
\text { over 100) }\end{array}$ \\
\hline $\begin{array}{l}\text { Cocon reduced to } \\
\begin{array}{l}\text { a few transparent } \\
\text { threads }\end{array}\end{array}$ & $\mathrm{L}$ & $\begin{array}{l}\text { Cocon usually pre- } \\
\text { sent but transpa- } \\
\text { rent }\end{array}$ & $\begin{array}{l}\text { Cocon usually pre- } \\
\text { sent, pigmented, } \\
\text { without defined } \\
\text { form }\end{array}$
\end{tabular}

Sternite and tergite of third abdominal segment separated by striated membraneous area

Tergite 5 without a row of spines; sternite 3 without hooks

Sternite and tergite fused together forming a ring without vestige of pleurite
Tergites 5-8 without a row of spines; sternite 3 with or without hooks
G

L

Abdomen with 2 Terminal hooks re-

Tergites 5-8 without a row of spines; sternites 3 and 4 without hooks
Fully developed onchotaxy long strong termi- duced

L $\mathbf{L}$ nal hooks

The larvae of Crozelia which are an element of the subantarctic fauna preserved the narrow head capsule of Gymnopais and Twinnia despite the presence of labral brush and labral fans in all the larval stages. The cephalic fans in this genus are reduced and have only the function of raking substrate and not water filtration (Davies, 1965; 1974).

In Prosimulium the premandibles are well developed and functional beginning from the second larval stage; the labral zone is widened considerably. However, the first larval stage shows a narrow labrum, a few cephalic fan rays and a labral brush similar to corresponding stages of the three other genera (Davies, 1960; 1965; Craig, 1974).

The monophyly of these four genera was confirmed in comparative studies on the evolution of cephalic fan rays, parts of torma and labral muscles of early larval stages (Craig, 1974).

The first larval stage of Levitinia was not studied until now. Nevertheless it is certain that the morphology of the head capsule of the subsequent stages (absence of cephalic fans, presence of well developed labral brush) allows to consider Levitinia as closely related to Twinnia and Gymnopais. This is also confirmed by cytological study on Levitinia tacobi in which Chubareva and Petrova (1981), found the same particular differences as in two primitive genera Twinnia and 
TABLE III. - Comparison between the last instar larva of the four genera related to the Prosimuliini.

\begin{tabular}{|c|c|c|c|}
\hline Levitinia & Gymnopais & Twinnia & Prosimulium \\
\hline Cephalic fan absent & $\mathrm{L}$ & L. & Cephalic fan present \\
\hline $\begin{array}{l}\text { Labral brush well de- } \\
\text { veloped }\end{array}$ & $\mathbf{L}$ & $\mathbf{L}$ & $\begin{array}{l}\text { Labral brush not de- } \\
\text { veloped (except in the } \\
\text { first larval stage) }\end{array}$ \\
\hline $\begin{array}{l}\text { Cephalic apotome wi- } \\
\text { dest in median part }\end{array}$ & $\mathbf{L}$ & $\mathbf{L}$ & $\begin{array}{l}\text { Cephalic apotome wi- } \\
\text { dest in third posterior } \\
\text { of its height }\end{array}$ \\
\hline $\begin{array}{l}\text { Postgenal cleft very } \\
\text { reduced }\end{array}$ & $\mathrm{L}$ & $\mathrm{L}$ & $\begin{array}{l}\text { Postgenal cleft varia- } \\
\text { ble, generally wide } \\
\text { and not deep }\end{array}$ \\
\hline $\begin{array}{l}7-8 \text { irregular row of } \\
\text { spine-like outgrowths } \\
\text { of cuticle on the ante- } \\
\text { ro-ventral region of } \\
\text { mandible }\end{array}$ & $\mathbf{L}$ & $\begin{array}{l}\text { Absence of out } \\
\text { growth of cuticle }\end{array}$ & (mandible different) \\
\hline $\begin{array}{l}6-8 \text { bristle-like cuticu- } \\
\text { lar outgrowths on la- } \\
\text { teral margins of hypo- } \\
\text { stoma }\end{array}$ & Short serrations & $\mathrm{G}$ & $\mathrm{G}$ \\
\hline $\begin{array}{l}\text { Antenna wholly dark } \\
\text { pigmented }\end{array}$ & $\begin{array}{l}\text { Third segment } \\
\text { only dark pig- } \\
\text { mented }\end{array}$ & $\mathrm{G}$ & G \\
\hline $\begin{array}{l}\text { Labrum narrow and } \\
\text { long; antenna not rea- } \\
\text { ching labral brush }\end{array}$ & $\mathbf{L}$ & $\begin{array}{l}\text { Labrum narrow } \\
\text { and proportional- } \\
\text { ly shorter; an- } \\
\text { tenna reaching } \\
\text { beyond labral } \\
\text { brush }\end{array}$ & Labrum wide \\
\hline $\begin{array}{l}\text { Anal sclerite with } \\
5 \text { branches }\end{array}$ & Sclerite Y-shaped & G & Sclerite X-shaped \\
\hline
\end{tabular}

Gymnopais (chromosomes homologues tightly paired, hardly visible centromeres, presence of nucleolar organized in chromosome I).

Considering the data of table $I I I$, it seems that the larvae of Levitinia are mainly close to those of Gymnopais. This is based on the following features: spinelike cuticular outgrowths on antero-ventral surface of mandible, rather long labrum as compared with antenna, and large development of labral brush.

On the other hand the larvae of Levitinia differ from those of Gymnopais and Twinnia by several characters: antennae entirely pigmented, cuticular bristle- 
like expansions on lateral margins of hypostoma and particular morphology of posterior sclerite (with 5 branches).

Table IV shows the principal characters for distinguishing the only two species that comprise the genus Levitinia.

TABLE IV. - Criteria for differentiation

Levilinia freidbergi Beaucournu-Saguez and Braverman from Levitinia tacobi Chubareva and Petrova.

\begin{tabular}{ll}
\hline \multicolumn{1}{c}{$L$. freidbergi } & \multicolumn{1}{c}{$L$. tacobi } \\
\hline 8 respiratory filaments & 10 respiratory filaments \\
\hline $\begin{array}{l}\text { Respiratory filaments arise from 2 main } \\
\text { trunks }\end{array}$ & $\begin{array}{l}\text { Respiratory filaments arise from } \\
3 \text { trunks }\end{array}$ \\
\hline $\begin{array}{l}\text { Central group of teeth of anterior mar- } \\
\text { gin of hypostoma very blunt }\end{array}$ & Central group of teeth prominent \\
\hline $\begin{array}{l}\text { Mandible with fifth apical tooth shorter } \\
\text { than the fourth }\end{array}$ & $\begin{array}{l}\text { Fifth tooth of the same length as } \\
\text { the fourth }\end{array}$ \\
\hline
\end{tabular}

\section{Ecological and biogeographical notes}

General description of the zoogeography and geography of the Golan Heights was already given by one of us (Braverman et al., 1981). The sampling site area

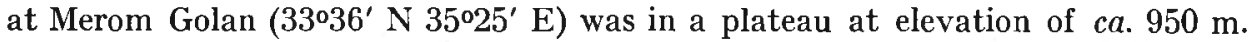
The Simuliidae samples were taken from a tiny winter stream which dries out during mid-May. The source of the water is rainfall which in this area of northern Golan Heights amounts to annual average of $822 \mathrm{~mm}$ (Israel Meteorological Services). In 1980-1981 the annual rainfall was $1,142.9 \mathrm{~mm}$ and in $1981-1982$ it was $748.5 \mathrm{~mm}$. Stream width was $0.85-2.7 \mathrm{~m}$; depth $0.20-0.45 \mathrm{~m}$; speed of flow 2.5 sec per $1 \mathrm{~m}$; stream bed consists of soil and basalt stones, water was fully exposed to the sun. The other Levitinia species $i$. e. L. tacobi was found only in Gissorky mountains not far from Takob village in the Tadjikistan Republic. It was collected in June 2, from a small mountain stream a an altitude of $2,000 \mathrm{~m}$.

Acknowledgments. Thanks are due to Dr. A. Freidberg, Tel-Aviv University, for providing us the University simuliid Collection, to Dr. Simitzis-Le Flohic of the Faculty of Medicine in Brest for taking the S. E. M. micrographs and to Dr. Pierre Vernon, of the Biological Station of Paimpont (University of Rennes) for providing us with diversified material of Crozetia crozetensis. Special thanks are extended to Pr. J. M. Doby for initiating the joint project. 


\section{REFERENCES}

Beaucournu-Saguez F., Rrvosecchi L. : Contributo alla conoscenza dei simulicli italiani : XXIV : Sulla presenza nelle alpi occidentali (Val d'Aosta) di una specie del gen. Twinnia (subf. Gymnopaidinae). Riv. Parass., 1982, 43, 47-50.

Braverman Y., Delecolle J. C., Frish K., Rubina M. : New records of Culicoides species (Diptera: Ceratopogonidae) from Golan Heights, Israel and Sinai peninsula. Israel J. Entom., $1981,15,13-20$.

Chubareva L. A., Petrova N. A. : (A new genus of black-flies (Diptera, Simulidae) from Tajikistan). Ent. Obozr., 1981, 60, 898-900 (In Russian).

Craig D. A. : The labrum and cephalic fans of larval Simuliidae (Diptera: Nemalocera). Can. $J$. Zool., 1974, 52, 133-159.

Crosskey R. W. : A preliminary revision of the black-flies (Diptera: Simuliidae) of the Middle East. Trans. R. Ent. Soc. Lond., 1967, 119, 1-45.

Crosskey R. W. : A re-classification of the simuliidae (Diptera) of Africa and its islands. Bull. Br. Mus. Nat. Hist. (Ent.), 1969, Suppl., 14, 1-95.

Crosskey R. W. : Simuliid taxonomy, the contemporary scene, pp. 3-18. In: Laird M. (ed.), Blackflies the future for biological methods in integrated control. Academic Press, London, 1981 , XII + 399 p.

Crosskey R. W. : The authorship, dating and application of suprageneric names in the Simuliidae (Diptera). Ent. Month. Mag., 1985, 121, 167-178.

Davies L. : The first-instar larva of a species of Prosimulium (Diptera: Simuliilae). Can. Ent., 1960, $92,81-84$.

Davies L. : The structure of certain atypical Simuliidae (Diptera) in relation to evolution within the family, and the erection of new genus for the Crozet Island black-fly. Proc. Linn. Soc. Lond., 1965, 176, 159-180.

Davies I.. : Evolution of larval head-fans in Simuliidae (Diptera) as inferred from the structure and biology of Crozetia crozetensis (Womersley) compared with other genera. Zool. J. Linn. Soc., $1974,55,193-224$

Dumbleton L. J. : Aberrant head-structure in larval Simuliidae (Diptera). Pac. Insects, 1962, 4, 77-86.

Grenier P., Rageau J. : Simulies (Dipt. Simuliidae) de Tahiti. Remarques sur la classification des Simuliidae. Bull. Soc. Pathol. Exot., 1960, 33, 717-742.

Novak V. J. A. : Twinnia hydroides sp. n. (Diptera, Simuliidae), ein Vertreter der unterfamilie Gymnopainae Rubz. in Europa. Zoologischer Anzeiger, 1957, 159, 168-174.

Peterson B. V. : The Prosimulium of Canada and Alaska (Diptera: Simulidae). Mem. Ent. Soc. Can., 1970, 69, 1-216.

Peterson B. V. : Simuliidae (pp. 355-391), in: MacAlpine J. F, and coll., Manual of Nearctic Diptera, Vol. I. Research Branch Agricultural Canada, 1981, Monography, no 27.

Rivosecchr L. : Fauna di Italia. Vol. 13 : Simuliidae (Diptera: Nematocera). Ed. Calderini, Bologna, 1978, 1-529.

Rubtsov J. A. : "Simuliidae (Melusinidae)", in : Lindner E., Ed. Die Fliegen der Palaerktischen Region, 1959-1964, 14,1-689.

RuBrsov I. A. : On the evolution, phylogeny and classification of blackflies (Simuliidae: Diptera). Trudy Zool. Inst. Leningr., 1974, 53, 230-282 (In Russian).

Rubtsov I. A., Yankovsky A. V. : Taxonomic key of genus of Simuliidae from palearctic region. Opredel. Faune SSSR, 1984, 142, 174 p.

Shewell G. E. : Classification and distribution of Arctic and Subarctic Simuliidae. Proc. Xth Int. Congr. Ent., Montreal, 1958, 1, 635-643.

Stone A. : An annotated list of genus-group names in the family Simuliidae (Diptera). Uniled States Department of Agriculture Technical Bulletin, $\mathrm{n}^{\circ} 1284,1963,28 \mathrm{p}$.

Stone A. : Simulidiae and Thaumaleidae, in: Guide to the insects of Connecticut, part VI. The diptera or true flies of Connecticut 9 th fascicle. Bull. Conn. St. Geol. nat. Hist. Surv., 1964, 97, 1-126.

Wood D. M. : Taxonomy of the nearctic species of Twinnia and Gymnopais (Diptera: Simuliidae) and a discussion of the ancestry of the Simuliidae. Can. Ent., 1978, 110, 1297-1337. 